TURIZAM

Volume 13

Issue 2, 102-112 (2009)

\title{
The New Age of faith tourism and Fruska Gora mountain (Serbia)
}

\author{
Igor Stamenković* 。 \\ Jovan Plavša* \\ Miroslav Vujičić*
}

Received: June 2009 | Accepted: December 2009

\begin{abstract}
In general, pilgrimage is a journey from home to a far sacred place for the purpose of spiritual enrichment (Raj, Morpeth, 2007). This paper is concerned with the possibility for development of religious tourism on Fruska Gora mountain. Nowdays, monasteries and sacred objects and places are the pilgrimage destinations for Orthodox and other Christians and religious belivers, in the Serbia. For instance, the Krušedol monastery is one of sixteen Serb's Orthodox monasteries on the Fruška Gora mountain in the northern Serbian province of Vojvodina. The monastery is the legacy of the last Serbian despot family of SremBranković. As a form of movement, pilgrimage has always been an active encounter with uncertainty. The main issue of this paper is to emphasize the importance of gaining modern management and marketing strategies and suggests, in oder to make better relationship between Orthodox church and religious tourism. Also, the purpose of this paper is to represent this Christian Holy place as strong touristic destinations that are visited by thousands of tourists and pilgrims. The Year of Faith Tourism 2009, hosted by the World Religious Travel Association (WRTA), is a year dedicated to the promotion of and participation in Faith Tourism. All sectors of society are encouraged to become involved including the media, governments, travel providers/suppliers, and people of faith.
\end{abstract}

Key words: religious tourism, Fruska Gora, Orthodox church, WRTA.

* Department of Geography, Tourism and Hotel Management, Faculty of Science, University of Novi Sad, Trg Dositeja Obradovića 3, 21000 Novi Sad, Serbia

- Corresponding author: igor.stamenkovic@dgt.uns.ac.rs 


\section{Introduction}

When the often called "saint" Fruska gora mountain is in question, it is undoubtfully the faith and tourism product which makes the Balkans region highly attractive for tourists from all over the world. Similarly, this mountain, with over 200 sacral buildings of various religions, attracts profane tourists and religious people, i.e. pilgrims (Stamenković, 2009).

Since faith tourism in this part of Europe is mostly related to inland arrangements with coach and car transport, it is necessary to review the transport infrastructure in Serbia. Similar arrangements in America have been coupled with cruises and air transport, whereas visits to numerous European and Roman-Catholic shrines are offered exclusively by walking routes. In order to provide safe and comfortable arrival and accommodation for tourists in receptive places in Serbia, it is necessary to conduct professional studies on the improvement of both local and regional infrastructure. The present condition of the roads (their category, physical and functional deterioration) does not provide safe and fast travelling. Therefore, it is necessary to build ancillary objects such as precise signposts and information boards; parking space around monasteries, toilet facilities, complementary services (repairs, car wrecker service, health service, etc.), modern petrol stations, shops, etc. Road Pan European Corridor X (Map 1) runs through Serbia with its two branches, making the main transport artery of the Balkans and creating possibilities for all types of short-stay tourism development: transit, business, congress, cycling tourism and also faith tourism (Stamenković, 2009). Air transport in Serbia is possibly in the worst condition. Some of the problems include: deterioration of aircraft fleet, necessity of additional international airport, necessity of a number of smaller, local or sports airports and also infrequent direct flights to numerous emittive countries in the world. It is necessary to point out that water transport (Corridor VII) on the Danube is in constant increase with small but steady pace. This transport facility is bringing more and more tourists to Vojvodina and Serbia. Thus, a special opportunity for further affirmation is given to monasteries of Fruska gora, archaeological sites and fortifications on the banks and near the Danube river. This might be a proper place to cite a thinker and a visionary: "Serbia will become unrecognizable. It will be the country of excellent roads and thousands of factories near them. It will become a large European transport centre with a cargo airport in Belgrade, Corridor X, the Danube river and Belgrade-Bar railway road. Certainly, it will become a transport centre of this part of the world" (Đinđić, 2005).

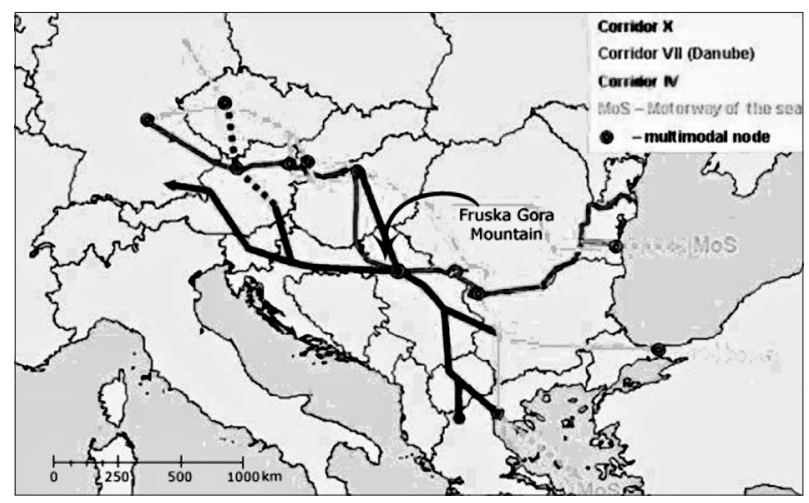

Figure 1. Pan-European corridors passing through Serbian are significant for faith tourism development and the position of Fruska Gora mountain (Source: http://www.koridor 10/search/) 


\section{Fruska Gora mountain as a saint mountain}

Tourists encounter places of religion in nearly every corner of the world. Wherever religious people have made places of interaction with sacred powers, touristic practices are able to establish a site worthy of visitation. At religious sites that host significant numbres of tourists, simultaneity of places emerges in paralle geographies of both the sacred and the touristic (Raj, Morpeth, 2007).

Each year more than 200 million Christians embark on trips around the world. Chritians visit places ranging from Mt. Sinai, where Moses received the Ten Commandments, to Bethany-beyond-the-Jordan, where John the Baptist baptized Jesus, and to Turkey and Greece, where the apostle Paul preached the Good News. In adition, Christians journey throughout Europe each year visiting the Vatican, the Reformation sites in Germany, and even C.S. Lewis's home, The Kilns, in England (Wright, 2008). And what about the Republic of Serbia and are there anything interesting for spiritual touristis?

The Republic of Serbia has more than 100 live monasteries which represents the unique potentials for development of faith-based tourism in Balkan region. Especially interested, among the others are sixteen Serb's Orthodox monasteries on the Fruska Gora mountain in the northern Serbian province of Vojvodina. Each monastery is the legacy of the some Serbian despot family and has it's own complete history, architecture and spiritual significance. Therefore, nowdays these monasteries are a pilgrimage destinations for Orthodox and other Christian and religious believers. According to historical data, these monastic communities were historically recorded since the first decades of the $16^{\text {th }}$ century. Legends, however, place their founding to the period between the $12^{\text {th }}$ and $15^{\text {th }}$ centuries (Vidić, 2007).

Krusedol is one of the more significant monasteries on Fruska Gora, having been built by the $16^{\text {th }}$ century ruler Djordje Brankovic, who led the Serbs in Hungarian exile. For Serbs under Ottoman rule in the south, Krusedol stood as an important religious, political and cultural center (Photo 1 and 2). Krusedol monastery was built between 1509 and 1516 It is the legacy of Vladika (Orthodox Church equivalent to bishop) Maksim Brankovic, son of the Serbian ruler Stefan, and it was meant to be a mausoleum of family Brankovic. Later Serbian royalty and patriarchs were also buried here, including the $19^{\text {th }}$ century King Milan Obrenovic, Dutchess Milica Obrenovic and Patriarch Arsenije II Carnojevic, leader of the $17^{\text {th }}$ century's great migration of Serbs northward. The beautifully painted wall frescoes at Krusedol have been well-preserved, and the carved wood iconostasis was done in a traditional national style, with some
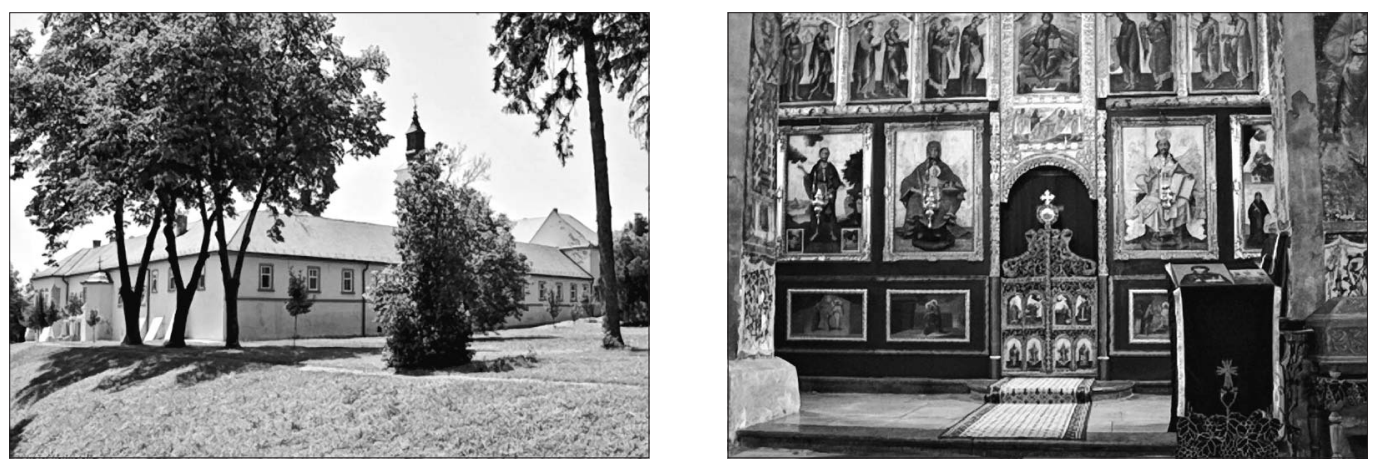

Figure 2. and 3. Iconostas' is of Krusedol monastery and its immediate surroundings Source: http://www.upload.wikimedia.org/wikipedia/commons/d/d3/Kru\%C5\%Aledol_monastery.jpg, http://www.flickr. com/photos/yckx/2767684050/sizes/o/ 
of its icons dating back to the $17^{\text {th }}$ century. Today's baroque look emerged during renovation, which began in 1722 and lasted until the middle of $18^{\text {th }}$ century. Fragments from the frescos depicting lives of saints are partially preserved. Icon pulpit divider Crucifixion, largely belongs to the period before monastery's restoration (Popović, 2008).

\section{Religious commitment of Serbian population as a prerequisite for successful development of domestic faith tourism offer}

According to Table 1 and the population census data in 2002 it may be concluded that out of the total population in Serbia (about 7.5 million) there are 40,068 atheists (0.53\%), 197,031 indecisive (agnostics and other) and more than 137,00o who fall within the category unknown, which makes about $4.5 \%$. That makes in total 347,000 or only $5 \%$ of those who do not belong to the category of religiously determined, which is to a certain extent unanticipated for a country where atheism had the status of states' religion for decades.

Conversely, the population census in 2002 showed that about $95 \%$ of the citizens belong to one of the churches or religious groups. About 6.4 million citizens belong to Serbian Orthodox Church, 411,00o to Roman Catholic Church, 240,00o to Islam Religion and about 81,00o to Protestant Church. The fact is that the citizens recognize not only their spiritual and cultural orientation but also their ethnic identity by expressing their religious belief. Almost 20,000 of worshippers belong to a religious group which is not among the above cited. Only 473 citizens express their religious belief but do not wish to belong to any religious group. Those people also might have honourable, humane and positive characters, but presumably wish to distance from religious groups and thus make a new category in that sense.

Serbs mainly belong to Serbian Orthodox Church (Population Census, 2002), but also partly to new churches and religious groups: Baptists, Adventists, Jehovah's Witnesses and other new Evangelistic Churches. Slovak national minority identifies with their Slovak Evangelistic Church; Hungarians mainly belong to Roman Catholic Church and to Calvin Christian Reformed Church. Ruthenians and Ukrainians in Vojvodina have found support in Greek Catholic Church for their ethnic specificities. Bunjevci national minority searches for recognition within Roman Catholic Church and approval of its ethnic specificity, i.e. their survival against assimilation from Croats. Croatian national minority is the strongest and the best organised national group within Roman Catholic Church in Serbia. Albanian national minority mainly belongs to Islam religion, with a smaller part which belongs to Roman Catholic Church and there have also been records of their accepting new Protestant Churches lately. A similar confessional differentiation is recorded among Roma ethnic group, but they belong to Islam religion and Serbian Orthodox Church with the almost equal shares.

The facts clearly indicate that Serbia is an autochthonous and multi religious state freely allowing activities to not only large traditional churches (Orthodox and Roman Catholic), but also to old Protestant Churches (Lutheran and Calvin) but also to new Christian Evangelistic Churches that emerged in Europe and America during the $19^{\text {th }}$ and $20^{\text {th }}$ centuries. Islam Religious group in Serbia has been present since the $14^{\text {th }}$ century and Jewish religion and their ethnic community since the $16^{\text {th }}$ century. The main feature of the religious structure in Serbia is that its multi religiousness is autochthonous, meaning that new religious beliefs were not brought by immigrants, but by domicile population which devoted their beliefs to numerous confessions and religious groups. Due to that fact, today's Serbia is, from religious aspect, an open country since its religious structure is modern and European in character. 
Table 1. Population of the Republic of Serbia according to religion

\begin{tabular}{|l|r|r|r|r|r|r|}
\hline & \multicolumn{1}{|c|}{ Total } & \multicolumn{1}{c|}{ Islamic } & \multicolumn{1}{c|}{ Judas } & \multicolumn{1}{c|}{ Chatolic } & \multicolumn{1}{c|}{ Orthodox } & Protestant \\
\hline $\begin{array}{l}\text { Republic of } \\
\text { Serbia }\end{array}$ & 7498001 & 239658 & 785 & 410976 & 6371584 & 80837 \\
\hline $\begin{array}{l}\text { Central } \\
\text { Serbia }\end{array}$ & 5466009 & 231585 & 456 & 22663 & 4970109 & 8678 \\
\hline $\begin{array}{l}\text { Vojvodina } \\
\text { province }\end{array}$ & 2031992 & 8073 & 329 & 388313 & 1401475 & 72159 \\
\hline $\begin{array}{c}\text { Prooriental } \\
\text { cults }\end{array}$ & $\begin{array}{c}\text { Believer } \\
\text { (church not } \\
\text { mention) }\end{array}$ & $\begin{array}{c}\text { Believer (not } \\
\text { member) }\end{array}$ & No category & Unbeliever & Unknown \\
\hline $\begin{array}{l}\text { Republic of } \\
\text { Serbia }\end{array}$ & 530 & 18768 & 473 & 197031 & 40068 & 137291 \\
\hline $\begin{array}{l}\text { Central } \\
\text { Serbia }\end{array}$ & 364 & 14312 & 55 & 95887 & 27485 & 94415 \\
\hline $\begin{array}{l}\text { Vojvodina } \\
\text { province }\end{array}$ & 166 & 4456 & 418 & 101144 & 12583 & 42876 \\
\hline
\end{tabular}

Source: Census of population, households and apartments in 2002 and Republic Statistical Office, 2003

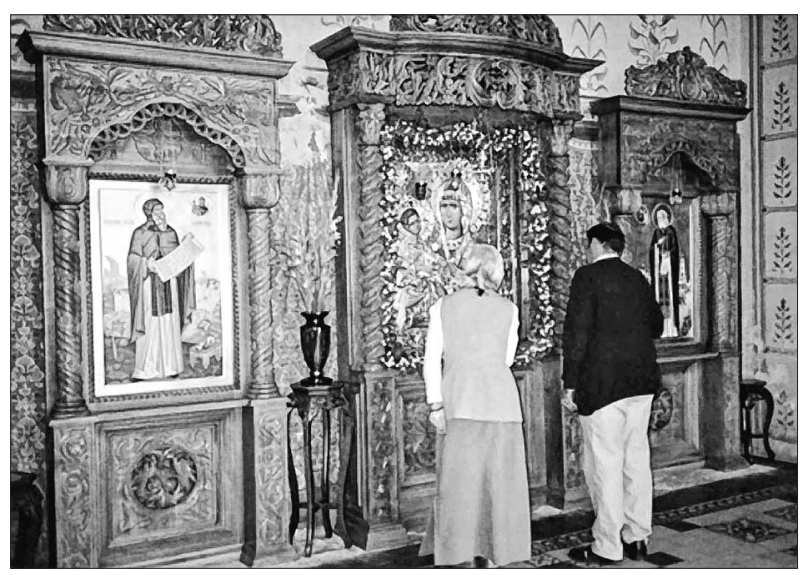

Figure 4. Worshippers in front of the icon of Holy Mother of God Trojeručica (three hands) in the Grgeteg monastery Source: http://www.flickr.com/photospelagija/499778946/sizesl

Dynamic and versatile religious structure of the present Serbia represents a strong potential in the democratic processes within the society and organisation of faith tourism travelling. The available data indicate a high potential within domestic faith tourists. There are growing numbers of domestic people heading towards spiritual centres and shrines (Photo 3 ).

\section{Laws and legal documants in favour of sustainable religious tourism development on Fruska Gora Mountain}

Crucial act in the process of organisation of religious tourism in Serbia and its monasteries is the enactment of the Law on Churches and Religious Communities by the National Assembly of the Republic of Serbia on April 20, 2006. This document is of highest importance for tour- 
ists and pilgrims who have developed a culture of visiting holy places, primarily after several decades' long atheistic tyranny of the communist regime. It has to be emphasized that one of the safety preconditions is the part of the law about the Restrictions on Religious Freedom. The Article 3 of this Law reads:"Freedom to religion and religious belief may be subject only to such restrictions as are prescribed by the Constitution, laws and ratified international documents and are necessary in a democratic society to protect public safety, public order, moral, and for protection of the freedom and rights of others. Religious freedom may not be used in such a way to either threaten the right to life, the right to health, the right of the child, right to personal and family integrity and right to property, or to provoke and instigate religious, national and racial intolerance".

The part of the Law on Protection of Property in Article 27 cites that: "Sacral and cultural heritage of Churches and religious communities, including immovable cultural goods, may not be dispossessed. Until the decision on restitution of property to Churches and religious communities is passed the relevant state body or the local self-government body may, at the request of a Church or religious community and pursuant to the law, cede for use the confiscated property or its parts." This means that all property transactions concluded as of March 2006 are invalid. Also, there have been about 20 restitution law models presented since 1995. It is necessary to implement natural proprietary restitution (exchange or natural substitution) of land and buildings. About 45,0oo hectares (o.5\% of the total area of Serbia) is still problematic in terms of ownership. The most property claims (about 70o) have been submitted by Serbian Orthodox Church. The main problem about this is the lack of land register for Southern, Western and Eastern Serbia by 1953, which further complicates the process of infrastructure construction, building accommodation capacities and other elements for reception of domestic and foreign worshippers and tourists. Numerous monasteries own real estate objects outside their complexes which might be used for providing various facilities or services (Stamenković, 2009).

The part of the Law that refers to Informatory and publishing activity in Article 43 cites: "In compliance with the Constitution and relevant laws and with an aim of advancing religious freedoms and freedom of information Churches and religious communities have the right to use public broadcasting service, as well as to independently conduct their own informatory and publishing activity..." This means that confessions have the rights to individually select the best means and forms of presenting their cultural and spiritual heritage to both general and tourism public.

All the above mentioned parts should be amended by acts referring to organisation of faith tourism, with the highest responsibility assigned to state and broadcasting service used to promote pilgrimages. Moreover, funds should be established for financing certain marketing projects, promotion at fairs and other presentation materials (multi language brochures, tourist postcards, thematic maps intended for a certain profile of tourists and localities, promotional films, billboards, banners, websites containing accurate and updated information, etc.).

Unfortunately, the Law on Tourism enacted in 2005, the new draft of the Law on Tourism in 2009, Strategy of Tourism of the Republic of Serbia in 2006 and other documents insufficiently recognise the potential of numerous Christian and other worship sites in Serbia (on Fruska gora) and the Balkans. All the competent institutions including the Ministry of economy and regional development, Tourist Organisation of Serbia, Serbian Orthodox Church and Institutions of Higher Education should define aims and priorities of future development by means of legal regulations, acts and protocols. 


\section{Scientific meetings devoted to faith tourism development in Serbia}

Scientific debate "Faith tourism as a part of sustainable development of Fruska gora" was held at the Faculty of Sports and Tourism TIMS in Novi Sad on December 12 and 13, 2008 (Photos 4 and 5). The basic idea for organisation of the debate was focused upon the celebration of five centuries of Krusedol monastery. The aims of the two-day debate were exchange of knowledge, ideas, opinions as well as design of optimal image of cultural, religious and tourist presentation of monasteries on Fruska gora in concordance with the basic principles of sustainable development. Special emphasis was given to possible forms of reconnection of monasteries with monastery estates and villages on Fruska gora through creating favourable conditions and supporting economic activities in villages (Scientific debate programme, 2008).

Scientific debate appeared highly constructive in the sense of the most important conclusions and proposals brought for designing the "Protocol of monastery visits on Fruska gora" in cooperation with Srem Diocese, which would be used as a written codex of ethical and moral principles intended for all participants in tourism sector (tourists, service providers - tourist economy and
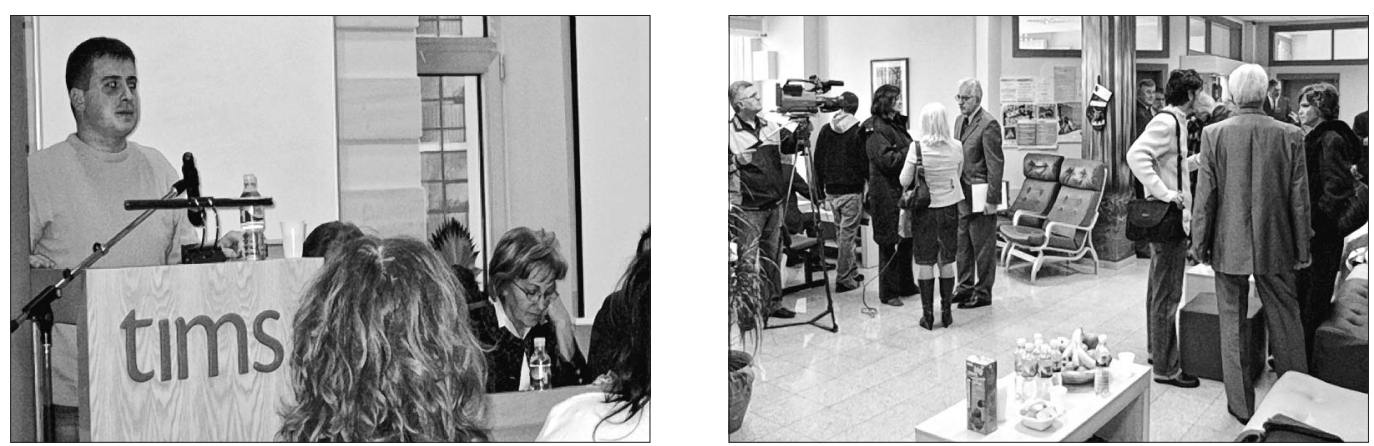

Figure 5. and 6. Scientific debate on sustainable faith tourism on Fruska gora held at the Faculty TIMS, Novi Sad, 2008

Source: photo, Stamenković, 2008.

local population). Furthermore, the conclusions were brought on designing and approval of special educational programmes for tourist guides-specialists in faith tourism and on the necessity of greater involvement of academic and higher education institutions concerning religious education of the population in Serbia (especially the young), highlighting the significance of religion and cultural values in general. There was true consent upon a special proposal about the usefulness of introducing low admission fees to monasteries on Fruska gora, with a small percentage of sojourn tax awarded to monastery maintenance. That would contribute to precise monitoring of tourists' turnover and introduce proper ethical codex in sacral destinations.

Following the first successful conference held on November $17^{\text {th }}, 2006$ at the Hotel Balkan in Belgrade with the topic, relationship between religions and tourism under the working title "To believe - to travel!" the second one was held on February $24^{\text {th }}, 2009$ at the same venue in Belgrade under the title "The Balkans - the place of pilgrimage!" Both conferences were organised by the Centre for faith tourism and pilgrimage studies, which is a part of Christian Cultural Centre in Belgrade, and gathered members of all religions, scientists, tourism employees, monastery dwellers and government representatives in charge of tourism organisation in Serbia. The conference mapped the main pilgrimage places in the Balkans, defined the future steps towards Serbia becoming the part of the faith tourism network tours of Europe and the world, established the future action plans and concluded that the leading role in faith tourism 


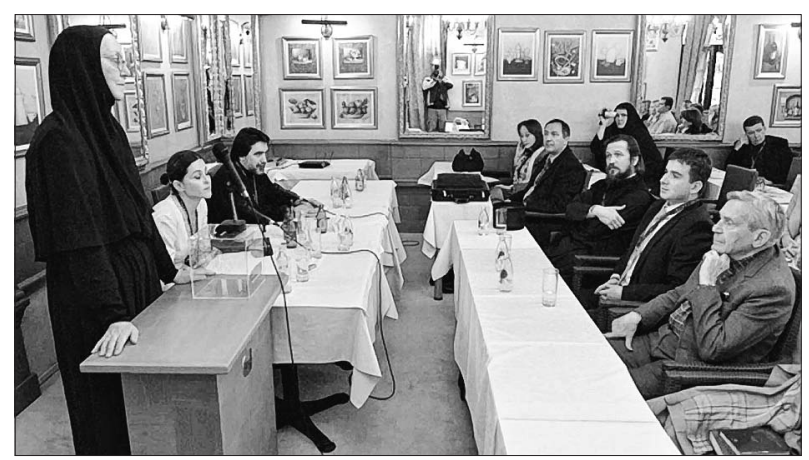

Figure 7. The first conference on faith tourism in the Balkan Hotel in Belgrade, 2006 Source: $h t t p: / / w w w . c c c . o r g . y u / k o n f e r e n c i j e . h t m \# 6$

development should be assigned to Serbian Orthodox Church and municipality tourist organisations (Photo 6). It was also pointed out that faith tourism should create the opportunity for the local population to actively participate in its organisation and that it would become a driving force of economic development in the settlements surrounding the sacred places and monasteries (Scientific meeting documents, 2006 and 2009).

Sister Bridget Lord, a nun from Manasija monastery and father Jovan, a monk from Ostrog monastery shared their experiences regarding their contacts with pilgrims and monastery visitors, as well as stories of their lives concerning decisions to live in a monastery. The second Conference pleanary speakers were members of the religions: bishop Porfirije, muftia Muhamed Jusufspahic, archbishop Stanislav Hocevar and Dragan Vukic from Pilgrimages' agency of Serbian Orthodox Church "Dobrocinstvo (Benefaction)". From its very foundation, the main idea of the Christian Cultural Centre in Belgrade has been to establish and promote joint activities of Christian communities in the Balkans, Europe and the world. The main motives for organisation of scientific conferences are the increasing visits to sacred places and shrines and the peoples' need of searching for truth and spiritual peace for their souls. Another reason for the conferences is the fact thea World Religious Travel Association declared the year 2009 as the year of faith tourism (Photo 7).

\section{World Religious Conference Management Association}

Religious Conference Management Association is a professional, non-profit and multi religious organization consisting of individuals responsible for planning and management of conferences, congresses, conventions, seminars and courses within their religious organisations. It was founded in 1972 and it has established the reputation of enhancing its members and joint associations. RCMA has been devoted to acquiring experiences in organisation of religious meetings all over the world. The association supports organisations and clients to gain knowledge, exchange experiences and broaden their professional expertise by joint ventures (http:// www.rcmaweb.org/AboutRCMA/tabid/63/Default.aspx).

Moreover, the better results have been achieved regarding decreased expenses in conference organisation, increased participation rate and higher quality spiritual effects on participants by application of new techniques and knowledge. Tourist destination branding is a method of reveling the specifics of a tourist place (important also for sacred places), it makes the implementation of the tourist facilities andis presented to tourists (Ivanović, Miličević, 2009). 


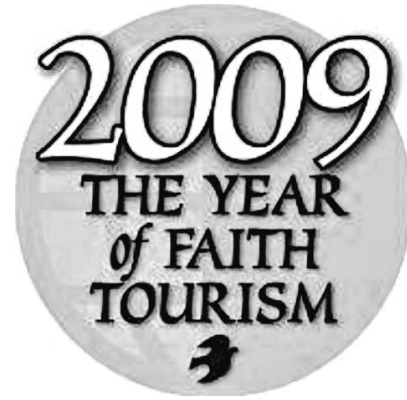

Figure 8. The symbol of promoting the year of faith tourism in the world Source: $h$ ttp://www. religiousmarket.blogspot. com/2008/07/year-of-faithtourism-proclaimed-by.html
Here also we need to emphasize the importance of these group of factors for one pilgrimage destiantion: socio-economic and psychological characteristics, level of usage, length of stay and tourist traffic by season, type of tourist activities and level of tourist satiosfaction (Jovičić, Dragin, 2008).

RCMA gathers about 3,400 members has organised over 16 ,ooo religious meetings for over 1,0oo denominations and religious organisations. The total annual number of participants in those meetings was about 14.8 million. The Association offers services of the experts employed in leading hotel chains, congress centres, reception and meeting acencies, aircarriers and other tourism and service organisations. This is also one of the forms of acquiring knowledge on various artistic and scientific techniques on religious meetings management. The $37^{\text {th }}$ World Coneference and Exhibition was held on January $29^{\text {th }}, 2009$ in Grand Rapids, Michigen. The renewal of annual memebership in the associations is $\$ 50.000$ and annual membership for new members is $\$ 100.000$ (http://www.rcmaweb. org/AboutRCMA/tabid/63/Default.aspx).

\section{What has to be done for revival of faith tourism on Fruska Gora Mountain?}

Institutionalised and well-established organisation of faith tourism in the monasteries of Fruska gora would be an opportunity to open new job posts and reduce poverty, which is still highly present in Serbia:

- for young population (jobs of guides, volunteer work, work at monastery estates, etc.),

- for older jobless population (help with the reception of guests, work at monastery estates),

- for theologians and religious teachers (opportunity to educate tourists and worshippers, provide useful information, organize lectures and workshops on religious topics, importance of pilgrimage and other spiritual issues.

- for worshippers a great opportunity to show their love to the neighbours (work with the monastery dwellers, philanthropic travelling, etc.)

If faith tourism is defined as a modern type of religious belief, then it could become the opportunity for establishing better communication between different groups of people; religious and cultural concepts; theologists and scientists; theologists and industrials, etc. Development strategy and action plans intended for pilgrimage tourism to certain types of monasteries is essential (Stamenkovic, 2006). First, the undesirable situations should be avoided, especially concerning the visits and admission to sacred places (monasteries and churches), among which the most frequent are the problems of proper clothing, taking photos and video recording, loud conversations, consummation of alcohol and cigarettes, weapons, pets, etc. Second, it is necessary to organise tourism information centres, particularly in the areas where there is a large number of sacred places, e.g. Fruska gora or Ovcarkso-kablarska gorge. The accesses to monasteries and entrances to cathedral churches should be provided with proper tourism signalling systems. It is advisable to publish ethical and moral codex manual for sacred places (protocols for visits). Animation of tourists on religious tours should contribute to overall quality of time spent and to comprehensible offers. The animation programme would include presentation of the life of a saint or retell a historical event, without shortening and remodelling the original data. Also, 
music evenings, poetry evenings or short story evenings would be organised by educated animation team including actors, musicians, gifted people who would visualise historical events of the church of a monastery for the tourists in an interesting and innovative way. The animation team might present the processes of making various items for common use, clothing items or food, or even demonstrate martial arts or knights' skills learned by monks in the past. All that would contribute to higher quality of animation for tourists, who wish to spend the time on a tour actively and usefully and quite differently from their everyday lives.

\section{Conclusion}

Based on the above documented issues, we could sublime all products, services and activities in a conclusion which might represent tourist offer of Krusedol monastery and other monastery complexes and sacral buildings on Fruska gora mountain. The offer of faith tourism would consist of the following:

- presence at religious services, masses, reading prayers for health;

- aspect and experience of the ambience (observation of the scenery, surrounding forests and green areas, falling of leaves, etc.);

- the sacral object with its authentic architecture and artistic value (painting, icon painting, fresco painting);

- exhibitions of treasures of religious art and religious service material;

- pilgrimage to relics and remains of the saints and miraculous icons;

- tasting brandy, wine, honey and bee products and other food produced in the monastery;

- music events, poetry evenings, choirs of spiritual music;

- schools of icon painting, woodwork and church singing

- educational workshops on theological research and personality psychology;

- animation in tourism (knight skills, plays on saints' biographies, etc.)

- volunteer work with older people, people with special needs and disabled;

- sports and recreational content - foot paths and cycle tracks, mountaineering;

- scientific and educational workshops (interrelation of science and religion - apologetics, discussions on the topics of creation, evolution, etc.)

- learning old crafts - weaving, embroidery, candle making, icons in crushing technique, other useful items and clothes;

- voluntary work at agricultural estates and assistance with the jobs inside monasteries and other activities.

Finally, the main role in the process of the process of creation and placement of faith tourism arrangements in Serbia is assigned to initiatives of various subjects (non government organisations, citizen initiatives, higher education institutions, tourism economy, tourism organisations and travel agents, ministry of economy and church institutions) to insist on more frequent discussions on this topic and the forms of flexible solutions to the problems and obstacles of future development. Moreover, it is necessary to make good contacts and relationships with church high officials at all levels since they are of highest importance in the process of worshippers' animation to participate in pilgrimage travelling. 


\section{References}

Documentation of scientific meeting, (2006), Believe - travel!, Christian Cultural Centre, Belgrade. (In Serbian)

Documentation of scientific meeting, (2009), Balkan, pilgrimage place, Christian Cultural Centre, Belgrade. (In Serbian)

Đinđić, Z., (2005), Metaphor, European Friendship Movement, Belgrade. (In Serbian)

Ivanović, M., Milićević, B., (2009), Some Challenges of Creating a New Brand of Serbian Tourism: Case study - The Republic of Užice, Turizam 13, Issue 1, Department of geography, tourism and hotel management, Faculty of Sciences, Novi Sad.

Jovičić, D., Dragin, A., (2008), The Assessment of Carrying Capacity - A Crucial Tool for Managing Tourism Effects in Tourist Destinations, International scientific journal Turizam, Vol. 12, Department of geography, tourism and hotel management, Faculty of sciences, Novi Sad.

Popović, T.Ž., (2008), Guide to the monasteries in Serbia, Intersistem, Belgrade. (In Serbian)

Census of population, households and apartments in 2002, Republic Statistical Office (2003), Belgrade. (In Serbian)

Documentation of scientific meeting, (2008), Religious tourism as a part of of Sustainable Tourism Development of Fruska Gora mountain, Faculty of sport and tourism - TIMS, Novi Sad. (In Serbian)

Raj, R., Morpeth, N.D., (2007), Religious Tourism and Pilgrimage management - An international Perspective, CAB International, UK.

Stamenković, I., (2006), Religious tourism and Orhodoxy, Department of geography, tourism and hotel management, Faculty of sciences, Novi Sad. (In Serbian)

Stamenković, I., (2009), Relation of Christian's churches toward religious tourism, MSc thesis, Department of geography, tourism and hotel management, Faculty of sciences, Novi Sad. (In Serbian)

Strategy of Tourism Development of the Republic of Serbia, (2006), Ministry of trade, tourism and services, Horwath Consulting Zagreb and Faculty of Economics in Belgrade, Belgrade. (In Serbian)

Timothy, D. J., Olsen, D.H., (2006), Tourism, religion and spiritual journeys, Routledge, UK.

Vidić, N., (2007), Specific touristic values of Fruska Gora mountain and its activation, the Serbian Geographical Society, Belgrade. (In Serbian)

Law on Tourism, (2005), Official Gazette of the Republic of Serbia, No. 45/05, Belgrade. (In Serbian)

Law on Churches and Religious Communities, (2006), Official Gazette of the Republic of Serbia, No. 36/06, Belgrade. (In Serbian)

Wright, J.K., (2008), The Christian Travel Planner, Thomas Nelson, USA.

Web sites:

http://www.ccc.org.yu/konferencije.htm\#6

http://www.flickr.com/photospelagija/499778946/sizesl

http://www.flickr.com/photos/yckx/2767684050/sizes/o/

http://www.koridor 10/search/

http://www.rcmaweb.org/AboutRCMA/tabid/63/Default.aspx

http://www.religiousmarket.blogspot.com/2008/o7/year-of-faith-tourism-proclaimed-by.html http://www.religioustravelassociation.com

http://www.upload.wikimedia.org/wikipedia/commons/d/d3/Kru\%C5\%A1edol_monastery.jpg 